Jurnal Akuntansi dan Perpajakan, 6(2): 91-100, 2020

http://jurnal.unmer.ac.id/index.php/ap

AKUNTANSY
PERPAJAKAY

\title{
Analisis Faktor Yang Mempengaruhi Tingkat Kelancaran Pengembalian Kredit (Studi Kasus Pada PT. BPR Kawan Malang)
}

\author{
Anggraeni Purwatiningsih¹, Irene Rani Pornamasari²
}

${ }^{1}$ Fakultas Ekonomi dan Bisnis Universitas Merdeka Malang, 65146, Indonesia

${ }^{2}$ Fakultas Ekonomi dan Bisnis Universitas Merdeka Malang, 65146, Indonesia

Keywords:

Cash Flow, Length of Business, Credit Returns

Kata Kunci:

Cash Flow, Lama Usaha, Pengembalian Kredit.

\section{ABSTRACT}

This study aims to analyze the characteristics of the borrower, the size of the loan, the economic sector, length of business, cash flow, and credit guarantees on the rate of return on credit at BPR Kawan. This type of research is a case study using a qualitative descriptive approach. Methods of data collection by conducting interviews, documentation, and observation. The sample used in the study amounted to 50 respondents who were active debtors of the Kawan People's Credit Bank from August to December 2019. The sampling technique used a random sample. The results showed that not all variables have an effect on the smoothness of credit repayments. Of all the research variables that do not have an effect, including the variable character of the borrower, the size of the loan, the economic sector, and credit guarantee. Meanwhile, the factors that influence the smooth return of credit at PT. Bank Perkreditan Rakyat Kawan is the length of business and cash flow. Duration of business and cash flow has a positive influence and relationship with the smooth return of credit. From the results of the regression coefficient of determination, it can be seen that $R$ Square is 0.619 . The amount of determination coefficient is 0.287 or equal to $61.9 \%$. This figure means that $61.9 \%$ of smooth repayment of credit can be explained by variables of the borrower's character, loan size, economic sector, length of business, cash flow, and credit guarantee, while the remaining $38.1 \%$ can be explained by causal factors other.

\begin{tabular}{l} 
ABSTRAK \\
\hline Penelitian ini bertujuan untuk menganalisis karakteristik \\
peminjam, besar pinjaman, sektor ekonomi, lama usaha, cash flow \\
dan jaminan kredit terhadap tingkat pengembalian kredit di BPR \\
Kawan. Jenis Penelitian ini merupakan studi kasus yang \\
menggunakan pendekatan deskriptif kualitatif. Metode \\
pengumpulan data dengan melakukan wawancara, dokumentasi \\
dan observasi. Sampel yang digunakan dalam penelitian \\
berjumlah 50 responden yang merupakan debitur aktif Bank \\
Perkreditan Rakyat Kawan pada bulan Agustus sampai dengan \\
Desember 2019. Teknik pengambilan sampel menggunakan \\
sampel Acak. Hasil penelitian menunjukkan bahwa tidak semua \\
variabel berpengaruh terhadap kelancaran pengembalian kredit, \\
dari semua variabel penelitian yang tidak memilki pengaruh \\
diantaranya variabel karakter peminjam, besar \\
pinjaman, sektor ekonomi dan jaminan kredit.
\end{tabular}


Sedangkan, faktor-faktor yang berpengaruh terhadap kelancaran pengembalian kredit di PT. Bank Perkreditan Rakyat Kawan adalah lama usaha dan cash flow. Lama usaha dan cash flow memiliki pengaruh dan keterkaitan positif dengan kelancaran pengembalian kredit. Dari hasil koefisien regresi determinasi terlihat bahwa $R$ Square sebesar 0.619. Besarnya angka koefisien determinasi 0.287 atau sama dengan 61,9\%. Angka tersebut memiliki arti bahwa sebesar $61,9 \%$ kelancaran pengembalian kredit dapat dijelaskan dengan variabel karakter peminjam, besar pinjaman, sektor ekonomi, lama usaha, cash flow, dan jaminan kredit, sedangkan sisanya yaitu 38,1\% dapat dijelaskan oleh faktor-faktor penyebab lainnya.

\section{PENDAHULUAN}

Kegiatan dari industri perbankan memegang peranan penting dalam perekonomian. Perkembangan dunia perbankan sekarang semakin meningkat dengan berbagai produk dan sistem usaha yang dipandang sebagai keunggulan kompetitif. Keadaan yang seperti ini telah mennghasilkan suatu sistem dan persaingan dalam dunia perbankan, bukan hanya persaingan antar bank saja tetapi antara bank dengan lembaga keuangan lainnya. Pengertian Bank menurut Undang-Undang nomor 10 tahun 1998 tentang perbankan indonesia sebagai penghimpun dan penyalur dana dari masyarakat yang bertujuan menunjang pelaksanaan pembangunan nasional ke arah peningkatan kesejahteraan masyarakat. Sehingga bank sangat berpengaruh besar untuk mendukung kegiatan perekonomian yang memberikan pelayanan dalam lalu lintas peredaran uang. Perbankan memiliki tugas pokok dalam upaya mendorong pencapaian tujuan nasional yang berhubungan erat dengan peningkatan dan pemerataan taraf hidup masyarakat.

Bank Perkreditan Rakyat (BPR) yang menyediakan jasa keuangan yang sama dengan bank umum memiliki penetrasi yang lebih baik khususnya bagi usaha mikro, kecil dan menengah. Seiring banyaknya persaingan di dunia perbankan, maka Bank Perkreditan Rakyat menjadi salah satu pilihan bagi masyarakat. Karena dalam pelayanan relatif lebih cepat, persyaratan lebih sederhana dan mudah dimengerti untuk kebutuhan nasabah. Masyarakat dapat menyimpan dana di Bank Perkreditan Rakyat yang dijamin oleh Lembaga Penjamin Simpanan (LPS) sama seperti di Bank umum, selama penyimpanan dana yang dilakukan sesuai dengan kriteria yang telah ditetapkan dan diawasi oleh Otorisasi Jasa Keuangan (OJK). Di sektor usaha mikro, kecil dan menengah masyarakat lebih memilih kemudahan dalam proses mencari modal dalam mengembangkan usahanya. Biasanya mereka tidak memiliki ijin secara formal dalam pendirian usaha tersebut.

Debitur melakukan peminjaman di Bank Perkreditan Rakyat dengan berbagai macam tujuan antara lain untuk penambahan modal usaha yang digunakan untuk menambah kapasitas atau pengembangan usaha, investasi yang digunakan untuk menunjang usaha yang jangka waktu pinjamannya lebih dari satu tahun dan konsumsi yang dipergunakan untuk kegiatan yang bersifat konsumtif seperti biaya pendidikan, pembelian elektronik, renovasi rumah, dll. Bank Perkreditan Rakyat memberikan fasilitas kredit sesuai dengan syarat dan ketentuan yang berlaku, dengan tujuan agar debitur bisa mengembangkan usaha dan memenuhi kebutuhan sehingga bisa mengembalikan pinjaman tersebut tepat waktu.

Suatu kredit dikatakan mencapai fungsinya jika secara sosial ekonomi baik bagi debitur ataupun kreditur membawa pengaruh yang baik. Fasilitas kredit yang diberikan oleh Bank Perkreditan Rakyat merupakan asset terbesar karena penghasilan utama dari Bank Perkreditan Rakyat adalah bunga, imbalan atau pembagian hasil usaha atas kredit yang diberikan. Bank Perkreditan Rakyat dalam memberikan fasilitas kredit mempunyai risiko kerugian yang besar, jika tidak dilakukan pengelolaan dan pengawasan yang baik akan mengancam kelangsungan hidup perusahaan tersebut. Banyaknya calon debitur yang melakukan kredit membuat pihak Bank Perkreditan Rakyat harus selektif dalam memberikan kredit. Dalam menentukan debitur yang layak diberikan kredit maka pihak BPR menerapkan prinsip kehati-hatian, dengan pemikiran bahwa yang mempengaruhi proses pemberian kredit adalah $5 \mathrm{C}$ yaitu character, capacity, 
capital, condition, dan collateral. Jika memenuhi kriteria dari 5C baru bisa dipertimbangkan untuk diberikan kredit yang harus dilakukan supervisi kembali oleh pejabat yang berwenang.

Permasalahan yang timbul dalam pemberian kredit oleh BPR sama seperti yang dialami lembaga keuangan lainnya yaitu pengembalian kredit dari debitur tidak selalu tepat waktu. Banyak terjadi kasus terhambatnya pengembalian kredit seperti penunggakan bahkan kemacetan pembayaran angsuran kredit. Selain itu, terhambatnya pengembalian kredit yang diberikan BPR bisa berasal dari faktor internal perusahaan sehingga dapat menurunkan tingkat likuiditas, solvabilitas dan rentabilitas bank yang pada akhirnya menyebabkan menurunnya kemampuan bank dalam membayar kewajiban hutang jangka pendek dan menghambat perputaran uang yang dapat berpengaruh terhadap profitabilitas bank (Kusumaningtyas, 2017).

Beberapa faktor yang mempengaruhi tingkat pengembalian kredit antara lain dari karakteristik peminjam, karakteristik usaha, karakteristik kredit, dan jaminan. Karakteristik personal merupakan sifat bawaan dari diri debitur sendiri. Hal ini berkaitan dengan kemauan dalam membayar angsuran kredit yang berpengaruh terhadap integritas dalam menjalankan kewajiban pembayaran kredit. Karakteristik usaha merupakan kondisi usaha yang dialami oleh debitur atau nasabah. Karakteristik usaha ini dapat dilihat antara lain dari kondisi usaha yaitu omzet usaha yang dapat mencerminkan tingkat pendapatan usaha tersebut. Pengajuan pinjaman kredit dilakukan sesuai dengan persyaratan dan jumlah kredit yang diajukan oleh debitur.

Penelitian ini bertujuan untuk menganalisis pengaruh karakteristik peminjam terhadap tingkat pengembalian kredit, enganalisis pengaruh besar pinjaman terhadap tingkat pengembalian kredit, menganalisis pengaruh sektor ekonomi terhadap tingkat pengembalian kredit, menganalisis pengaruh lama usaha terhadap tingkat pengembalian kredit, menganalisis pengaruh cash flow terhadap tingkat pengembalian kredit, dan menganalisis pengaruh jaminan kredit terhadap tingkat pengembalian kredit.

\section{METODE}

\section{Definisi Operasional Variabel}

Variabel dependen $(\mathrm{Y})$

Variabel dependen dalam penelitian ini adalah tingkat kelancaran pengembalian kredit. Tingkat kelancaran pengembalian kredit terdiri dari kredit lancar dan tidak lancar. Kredit lancar yaitu kredit yang tidak mempunyai tunggakan atau keterlambatan sama sekali yang pembayaran tepat waktu, sedangkan kredit tidak lancar yaitu kredit yang menunggak mulai dari satu kali dan seterusnya. Variabel dalam penelitian ini dikategorikan menjadi 2 yaitu : Skor 0 : Lancar dan Skor 1 : Tidak Lancar

\section{Variabel Independen $(X)$}

a. Karakter Peminjam

Karakter peminjam yaitu mengenai sifat dan latar belakang nasabah, kebiasaan hidup, pola hidup nasabah dalam keseharian dalam pergaulan di dalam lingkungan dan sekitar rekan bisnis. Penelitian ini lebih spesifik terhadap jenis kelamin peminjam. Varibel dalam penelitian ini dikategorikan menjadi 2 : Skor 1 : Laki-laki dan Skor 2 : Perempuan.

b. Besar Pinjaman

Besar pinjaman merupakan plafon atau besarnya dana yang diberikan oleh Bank kepada debitur. Besar pinjaman dihitung dalam rupiah dengan besar pinjaman maksimal sebesar Rp. 150.000.000,-

c. Sektor Ekonomi

Sektor ekonomi merupakan jenis usaha yang dijalankan oleh debitur, yang merupakan salah satu faktor yang mempengaruhi kelancaran pengembalian kredit. Penelitian ini dikategorikan menjadi dua yaitu pertanian yang mencakup bidang usaha pertanian, perternakan, pembibitan, perburuan sedangkan untuk non pertanian yang mencakup bidang usaha perdagangan, industri, jasa dan karyawan. Variabel penelitian dikategorikan menjadi dua yaitu : Skor 1 : Pertanian dan Skor 2 : Non pertanian

d. Lama Usaha

Lama usaha merupakan lamanya usaha atau pengalaman usaha yang telah dijalankan oleh debitur dalam mengelola bisnis atau perusahaannya, yang dhitung menggunakan satuan tahun. 
e. Cash Flow

Cash flow merupakan arus kas yang diterima oleh debitur setiap bulan yang mencerminkan kemampuan mengembalikan pinjaman. Cash flow merupakan indikator yang penting dalam penilaian kredit terhadap kredit calon debitur. Variabel dalam penelitian ini bisa dihitung dalam rupiah dari omset debitur dalam satu bulan.

f. Jaminan Kredit

Jaminan artinya bank menginginkan agar kredit yang diberikan itu terjamin dan akan kembali kepada bank setelah jatuh tempo sesuai kesepakatan bersama. Jaminan kredit berupa bukti pemilikan kendaraan bermotor dan sertifikat hak milik. Varibel dalam penelitian ini dibagi menjadi 2 yaitu : Skor 1 : Bukti Pemilikan Kendaraan Bermotor (BPKB), Skor 2 : Sertifikat Hak Milik (SHM).

\section{Sampel}

Sampel didefinisikan sebagai bagian dari populasi. Sampel merupakan bagian dari jumlah dan karakteristik yang dimiliki oleh populasi tersebut. Dalam penelitian yang menggunakan metode sampel dinilai dapat menghemat biaya serta penelitian akan dapat lebih cepat diselesaikan. Maka sampel yang diambil dari populasi harus betul - betul representatif (mewakili). Penentuan sampel dalam penelitian ini dilakukan secara acak terhadap semua debitur di PT. Bank Perkreditan Rakyat Kawan dan Sampel penelitian yang digunakan sejumlah 50 debitur.

\section{Teknik Analisa Data}

Teknik analisis data yang digunakan dalam penelitian ini analisis deskriptif dan analsiis regresi logistik. Analisis regresi Logistik merupakan model analisis untuk mengetahui pengaruh variabel-variabel yang berskala metrik (kontiyu) atau kategorik (nominal) terhadap variabel yang berskala kategorik. Model regresi yang digunakan dalam penelitian ini sebagai berikut :

$$
\text { Li }=\ln \left[\frac{\rho}{\rho-1}\right]=\beta_{0}+\beta_{1} x_{1}+\beta_{2} x_{2}+\cdots \cdots+\beta_{k} x_{k}
$$

\section{Keterangan:}

$\mathrm{Li}=$ Variabel dependen, dalam hal ini tingkat kelancaran pengembalian kredit $(1=$ lancar, $0=$ menunggak)

$\beta 0=$ Konstanta

$\beta 1=$ Koefisien variabel independen ke- 1

$\beta \mathrm{k}=$ Koefisien variabel independen ke- $\mathrm{k}$

$\mathrm{X} 1$ = Variabel independen ke-1

$\mathrm{Xk}=\quad$ Variabel independen ke-k

\section{HASIL}

Tujuannya untuk menguji dan menjelaskan karakteristik sampel yang diobservasi. Hasil uji statistik deskriptif biasanya berupa tabel yang berisi nama variabel yang diobservasi, mean, standar deviasi (standart deviation), maksimum dan minimum yang kemudian diikuti penjelasan berupa narasi yang menjelaskan interprestasi isi tabel tersebut (Chandrarin,2017: 139).

Berdasarkan analisis deskriptif dengan menggunakan SPSS Versi 22.0 diperoleh gambaran sampel sebagai berikut : 
Tabel 1. Deskriptif Statistik

Descriptive Statistics

\begin{tabular}{|l|r|r|r|r|r|}
\hline & $\mathrm{N}$ & Minimum & Maximum & Mean & Std. Deviation \\
\hline karakter & 50 & 1 & 2 & 1.34 & .479 \\
\hline Besar_Pinjaman & 50 & 10000 & 150000 & $7.56 \mathrm{E} 4$ & 45745.971 \\
\hline Sektor_Ekonomi & 50 & 1 & 2 & 1.52 & .505 \\
\hline Lama_Usaha & 50 & 2 & 17 & 8.26 & 4.332 \\
\hline Cash_Flow & 50 & 7000 & 85000 & $3.76 \mathrm{E} 4$ & 21876.425 \\
\hline Jaminan & 50 & 1 & 2 & 1.46 & .503 \\
\hline Pengembalian & 50 & 1 & 2 & 1.22 & .418 \\
\hline Valid N (listwise) & 50 & & & & \\
\hline
\end{tabular}

Sumber : data diolah

Berdasarkan tabel 1 karakter peminjam mempunyai rata-rata sebesar 1,34 artinya nilai rata-rata uku- ran karakter peminjam adalah $134 \%$ serta memiliki nilai standar deviasi sebesar 0,479 dengan 50 sampel.

Besar pinjaman mempunyai rata-rata sebesar 7,56 artinya nilai rata-rata ukuran besar peminjam adalah $756 \%$ serta memiliki nilai standar deviasi sebesar 45.745,971 dengan 50 sampel. Sektor ekonomi mempunyai rata-rata sebesar 1,52 artinya nilai rata-rata ukuran sektor ekonomi adalah $152 \%$ serta memiliki nilai standar deviasi sebesar 0,505 dengan 50 sampel. Lama usaha mempunyai rata-rata sebesar 8,26 artinya nilai rata-rata ukuran lama usaha adalah $826 \%$ serta memiliki nilai standar deviasi sebesar 4,332 dengan 50 sampel. Cash flow mempunyai rata-rata sebesar 3,76 artinya nilai rata-rata ukuran cash flow adalah $376 \%$ serta memiliki nilai standar deviasi sebesar 21.876,425 dengan 50 sampel. Jaminan Kredit mempunyai ratarata sebesar 1,46 artinya nilai rata-rata ukuran jaminan kredit adalah $146 \%$ serta memiliki nilai standar deviasi sebesar 0,503 dengan 50 sampel. Pengembalian kredit mempunyai rata-rata sebesar 1,22 artinya nilai rata-rata ukuran pengembalian kredit adalah $122 \%$ serta memiliki nilai standar deviasi sebesar 0,418 dengan 50 sampel.

\section{Persamaan Regresi Logistik}

Pengujian hipotesis dalam penelitian ini dilakukan secara uji multivariate dengan menggunakan regresi logistik (logistic regression) karena variabel dependen dalam penelitian ini bersifat dikotomi (Lancar dan Tidak Lancar). Tujuan dari analisis regresi logistik adalah mengetahui seberapa jauh model yang digunakan mampu memprediksi secara benar kategori group dari sejumlah individu. (Kuncoro, 2001).

Tabel 2. Regresi logistik

Variables in the Equation

\begin{tabular}{|ll|r|r|r|r|r|r|}
\hline & \multicolumn{1}{|c|}{ B } & \multicolumn{1}{|c|}{ S.E. } & \multicolumn{1}{|c|}{ Wald } & \multicolumn{1}{|c|}{ Sig. } & \multicolumn{1}{|c|}{$\operatorname{Exp}(\mathrm{B})$} & Ket \\
\hline Step 1 $^{\text {a }}$ & Karakter & 1,496 & 1,137 & 1,732 &, 188 & 4,466 & Tidak berpengaruh \\
& Besar_Pinjaman &, 000 &, 000 &, 010 &, 922 & 1,000 & Tidak berpengaruh \\
& Sektor_Ekonomi &, 918 & 1,082 &, 719 &, 397 & 2,503 & Tidak berpengaruh \\
& Lama_Usaha & -262 &, 130 & 4,044 &, 044 &, 770 & Berpengaruh \\
Cash_Flow &, 000 &, 000 & 5,067 &, 024 & 1,000 & Berpengaruh \\
Jaminan & 1,736 & 1,519 & 1,305 &, 253 & 5,672 & Tidak berpengaruh \\
Constant & $-1,029$ & 2,843 &, 131 &, 717 &, 358 & Tidak berpengaruh \\
\hline
\end{tabular}

a. Variable(s) entered on step 1: karakter, Besar_Pinjaman, Sektor_Ekonomi, Lama_Usaha, Cash_Flow, Jaminan. Sumber : data diolah 
Jurnal Akuntansi dan Perpajakan, 6(2): 91-100, 2020

http://jurnal.unmer.ac.id/index.php/ap

Dari tabel diatas maka dapat dibentuk persamaan regresi sebagai berikut :

$\mathrm{Y}=\mathrm{a}+\mathrm{b}_{1} \mathrm{x}_{1}+\mathrm{b}_{2} \mathrm{x}_{2}+\mathrm{b}_{3} \mathrm{x}_{3}+\mathrm{b}_{4} \mathrm{x}_{4}+\mathrm{b}_{5} \mathrm{x}_{5}+\mathrm{b}_{6} \mathrm{x}_{6}$

$Y:-1,029+1,496 x_{1}+0,000 x_{2}+0,918 x_{3}+(-0,262) x_{4}+0,000 x_{5}+1,736 x_{6}$

Cara untuk menganalisis regresi logistik dengan pendekatan probabilitas (Santoso, 2014) adalah :

1. Nilai negatif, dianggap probabilitas 0

2. Nilai positif lebih dari 1, dianggap probabilitas 1

3. Nilai positif antara 0 sampai dengan 1 , probabilitas disesuaikan dengan angka perolehan tersebut.

Dari persamaan regresi diatas maka dapat dilakukan analisis, dimana :

1. konstanta sebesar -1,029 yang berarti karakter peminjam, besar pinjaman, sektor ekonomi, lama pinjaman, cash flow dan jaminan kredit berpengaruh terhadap kelancaran pengembalian kredit. Kontanta bernilai negatif, maka probabilitas dianggap $=0$

2. Koefisien regresi variabel karakter peminjam sebesar 1,496 (bernilai positif) yang artinya kemungkinan dapat berpengaruh terhadap kelancaran pengembalian kredit.

3. Koefisien regresi variabel besar pinjaman sebesar 0,000 yang artinya kemungkinan tidak berpengaruh terhadap kelancaran pengembalian kredit.

4. Koefisien regresi variabel sektor ekonomi sebesar 0,918 yang artinya kemungkinan berpengaruh terhadap kelancaran pengembalian kredit.

5. Koefisien regresi variabel lama pinjaman sebesar -0,262 yang artinya kemungkinan tidak berpengaruh terhadap kelancaran pengembalian kredit.

6. Koefisien regresi variabel Cash Flow sebesar 0,000 yang artinya kemungkinan tidak berpengaruh terhadap kelancaran pengembalian kredit.

7. Koefisien regresi variabel Jaminan kredit sebesar 1,736 yang artinya kemungkinan berpengaruh terhadap kelancaran pengembalian kredit.

\section{Menilai kecocokan model}

Pengujian ini dilakukan untuk menilai model yang dihipotesiskan fit dengan data atau tidak. Pen- gujian dilakukan dengan membandingkan nilai antara - 2 log likelihood pada awal (blok number $=0$ ) dengan nilai 2 log likelihood pada akhir (blok number =1). Pengurangan nilai antara -2LL awal (initial-2LL function) dengan nilai $-2 L L$ pada langkah awal berikutnya menunjukkan bahwa variabel yang dihipotesiskan fit dengan data. Hal ini karena log likelihood pada regresi logistik mirip dengan "sum of square error" pada model regresi sehingga penurunan log likelihood menunjukkan model regresi semakin baik

Tabel 3. Hosmer and lemeshow test

Hosmer and Lemeshow Test

\begin{tabular}{|l|r|r|r|}
\hline Step & Chi-square & df & Sig. \\
\hline 1 & 14,537 & 8 &, 069 \\
\hline
\end{tabular}

Hipotesis :

$\mathrm{H}_{\mathrm{O}}$ : model yang terbentuk cocok dengan pengamatan

$\mathrm{H}_{\mathrm{a}}$ : model yang terbentuk tidak cocok dengan pengamatan

Dari hipotesis diatas maka kita tentunya tidak bisa menolak Ho supaya model yang terbentuk bisa cocok dengan data pengamatan

Dasar pengambilan keputusan:

1. Jika nilai sig hosmer and lomeshow test $>0.05$, maka Ho diterima

2. Jika nilai sig hosmer and lomeshow test $<0.05$, maka $\mathrm{H}_{\mathrm{a}}$ diterima

Analisis Dari tabel output spss hosmer and lomeshow test diatas terlihat bahwa nilai sig sebesar 0,489. Nilai tersebut lebih besar dari alpha penelitian $(0,069>0,05)$, maka jelas dapat menerima $\mathrm{H}_{\mathrm{O}}$ yang artinya model sudah cocok dengan data observasi, sehingga model regresi logistik ini layak untuk digunakan untuk tahap selanjutnya. 
Tabel 4. Iteration History ${ }^{a, b, c, d}$

\begin{tabular}{|ll|r|r|}
\hline Iteration & & -2 Log likelihood & $\begin{array}{c}\text { Coefficients } \\
\text { Constant }\end{array}$ \\
\hline Step 1 & 1 & 35,742 &,- 317 \\
& 2 & 28,839 &,- 681 \\
& 3 & 27,105 &,- 970 \\
& 4 & 26,898 & $-1,034$ \\
& 5 & 26,892 & $-1,029$ \\
& 6 & 26,892 & $-1,029$ \\
& 7 & 26,892 & $-1,029$ \\
\hline
\end{tabular}

a. Method: Enter

b. Constant is included in the model.

c. Initial -2 Log Likelihood: 52,691

d. Estimation terminated at iteration number 7 because parameter estimates changed by less than,001.

Tabel 5. Model Summary

\begin{tabular}{|l|r|r|r|}
\hline Step & $\begin{array}{c}-2 \text { Log likeli- } \\
\text { hood }\end{array}$ & $\begin{array}{c}\text { Cox \& Snell R } \\
\text { Square }\end{array}$ & $\begin{array}{c}\text { Nagelkerke R } \\
\text { Square }\end{array}$ \\
\hline 1 & $26,892^{\mathrm{a}}$ &, 403 &, 619 \\
\hline
\end{tabular}

a. Estimation terminated at iteration number 7 because parameter estimates changed by less than,001.

Dari tabel diatas terlihat bahwa nilai -2 Log likelihood mengalami penurunan dari step $0(52,691)$ ke step $1(26,892)$ artinya model regresi logistik yang terbentuk lebih baik. terlihat dari nilai Nagelkerke $R$ Square sebesar 0,619 yang artinya besaran pengaruh dari variabel Independen $\left(\mathrm{x}_{1}, \mathrm{x}_{2}, \mathrm{x}_{3}, \mathrm{x}_{4}, \mathrm{x}_{5}, \mathrm{x}_{6}\right)$ terhadap variabel Dependen (Y) adalah sebesar $62 \%$.

\section{Pengujian Hipotesis}

Pengujian hipotesis dilakukan untuk mengetahui pengaruh secara parsial antara masing-masing variabel independen terhadap variabel dependen.

Dengan dasar pengambilan keputusan:

1) Jika nilai sig <0,05 maka hipotesis diterima

2) Jika nilai sig $>0,05$ maka hipotesis ditolak

1. Uji hipotesis 1

Berdasarkan tabel diatas terlihat nilai signifikan untuk variabel karakter peminjam $\left(\mathrm{x}_{1}\right)$ sebesar 0,188 angka tersebut lebih besar dari alpha penelitian $(0,188>0,05)$ artinya secara parsial karakter peminjam tidak berpegaruh secara signifikan terhadap kelancaran kredit.

2. Uji hipotesis 2

Berdasarkan tabel diatas terlihat nilai signifikan untuk variabel besar pinjaman $\left(\mathrm{x}_{2}\right)$ sebesar 0,922 angka tersebut lebih besar dari alpha penelitian $(0,922>0,05)$ artinya secara parsial besar pinjaman tidak berpegaruh secara signifikan terhadap kelancaran kredit.

3. Uji hipotesis 3

Berdasarkan tabel diatas terlihat nilai signifikan untuk variabel sektor ekonomi $\left(\mathrm{x}_{3}\right)$ sebesar 0,397 angka tersebut lebih besar dari alpha penelitian $(0,397>0,05)$ artinya secara parsial sektor ekonomi tidak berpegaruh secara signifikan terhadap kelancaran kredit.

4. Uji hipotesis 4

Berdasarkan tabel diatas terlihat nilai signifikan untuk variabel lama usaha $\left(\mathrm{x}_{4}\right)$ sebesar 0,044 angka tersebut lebih besar dari alpha penelitian $(0,044<0,05)$ artinya secara parsial lama usaha berpegaruh secara signifikan terhadap kelancaran kredit. 
5. Uji hipotesis 5

Berdasarkan tabel diatas terlihat nilai signifikan untuk variabel cash flow $\left(\mathrm{x}_{5}\right)$ sebesar 0,024 angka tersebut lebih besar dari alpha penelitian $(0,024<0,05)$ artinya secara parsial cash flow berpegaruh secara signifikan terhadap kelancaran kredit.

6. Uji hipotesis 6

Berdasarkan tabel diatas terlihat nilai signifikan untuk variabel jaminan kredit $\left(\mathrm{x}_{6}\right)$ sebesar 0,253 angka tersebut lebih besar dari alpha penelitian $(0,253>0,05)$ artinya secara parsial jaminan kredit tidak berpegaruh secara signifikan terhadap kelancaran kredit.

\section{PEMBAHASAN}

Karakter peminjam tidak berpengaruh terhadap tingkat pengembalian kredit di BPR Kawan. Hal ini menunjukkan bahwa baik buruknya karakter peminjam tidak mempengaruhi tingkat pengembalian kredit di BPR Kawan. Karakteristik peminjam merupakan sifat dalam diri debitur atau nasabah. Hal ini terkait dengan kemauan dan kesungguhan membayar angsuran kredit yang tentunya sangat berpengaruh terhadap integritas dalam memenuhi kewajiban pembayaran kredit dan pemanfaatan pemberian kredit dengan benar. Hasil penelitian ini tidak mendukung Abadi (2014) yang menyatakan bahwa karakter debitur berpengaruh terhadap kelancaran pengembalian pinjaman.

Besar pinjaman tidak berpengaruh terhadap tingkat pengembalian kredit di BPR Kawan. Hasil penelitian ini mendukung Nastiti (2013) yang menyatakan bahwa jumlah pinjaman tidak berpengaruh terhadap tingkat pengembalian kredit. Besar pinjaman merupakan besarnya dana yang dipinjam oleh debitur kepada bank guna memenuhi kebutuhan dan dikembalikan beserta jumlah bunga sesuai dengan jangka waktu yang sudah ditentukan oleh kedua belah pihak. Sebagimana pendapat Muhamammah (2008:93) besarnya jumlah pinjaman yang diberikan oleh pihak bank hingga batas maksimum tergantung dari jumlah permintaan dan penilaian kemampuan membayar debitur. Semakin besar jumlah pinjaman yang diberikan, maka semakin besar beban yang harus ditanggung oleh debitur dalam pelunasannya, sehingga pemberian jumlah pinjaman yang terrlalu besar akan menimbulkan suatu risiko terhambatnya debitur dalam membayar kredit tersebut. Hasil penelitian ini tidak mendukung Lestari dan Rosha (2020) yang menyatakan bahwa jumlah pinjaman berpengaruh signifikan terhadap tingkat pengembalian kredit.

Sektor ekonomi tidak berpengaruh terhadap tingkat pengembalian kredit di BPR Kawan. Hal ini menunjukkan bahwa pengelompokan sektor ekonomi peminjam dilihat dari sektor pertanian maupun non pertanian tidak berdampak tingkat pengembalian kredit. Sektor ekonomi yang memiliki jumlah karyawan banyak akan mengurangi pendapatan yang seharusnya diterima oleh pemilik usaha karena sebagian pendapatan diterima oleh pemilik usaha harus dialokasikan untuk membayar gaji karyawan, sehingga akan meningkatkan peluang penunggakan kredit. Hasil penelitian ini mendukung Abadi (2014) yang menyatakan bahwa jenis usaha tidak berpengaruh terhadap kelancaran pengembalian pinjaman.

Lama usaha berpengaruh signifikan terhadap tingkat pengembalian kredit di BPR Kawan. Hasil penelitian ini mendukung Abadi (2014) yang menyatakan bahwa lama usaha berpengaruh signifikan terhadap tingkat kelancaran pengembalian KUR Mikro. Lama usaha peminjam sering menentukan keberhasilan usaha. Semakin lama seseorang menjalani usaha maka semakin handal dalam mengelola usaha sehingga semakin besar juga keberhasilan usaha meskipun tidak hanya hal itu yang menentukan keberhasilan usaha seseorang. Keberhasilan usaha tersebut juga akan menentukan tingkat keuntungan yang akan diperolehnya yang pada akhirnya menentukan pula kemampuannya dalam membayar angsuran kredit. Ini menjadi alasan untuk menduga bahwa lama usaha berpengaruh positif terhadap kelancaran pengembalian kredit

Cash flow berpengaruh signifikan terhadap tingkat pengembalian kredit di BPR Kawan. Hal ini menunjukkan bawah semakin tinggi cash flow pada usaha peminjam dapat meningkatkan tingkat pengembalian kredit. Cash flow dapat menjadi acuan rencana suatu perusahaan di masa mendatang. Cash flow usaha peminjam dikatakan sehat apabila uang yang masuk tidak terhambat dan jumlah uang yang keluar juga tidak melebihi pemasukan yang didapat. Kekurangan cash flow pada usaha peminjam akan kesulitan dalam berekspansi atau bahkan mengalami kebangkrutan karena kekurangan uang akibat cash flow yang selalu minus. Oleh karena itu kreditur harus melihat cash flow nasabah, sebagai salah satu syarat memperoleh kredit agar lancar dalam mengembalikan pinjaman. 
Jurnal Akuntansi dan Perpajakan, 6(2): 91-100, 2020

http://jurnal.unmer.ac.id/index.php/ap

Jaminan kredit tidak berpengaruh terhadap tingkat pengembalian kredit di BPR Kawan. Hal ini menunjukkan bahwa besar kecilnya jaminan kredit tidak berdampak pada tingkat kelancaran pengembalian kredit. Pemberian kredit dengan jaminan relatif lebih aman dibandingkan tanpa jaminan karena dapat menutupi kerugian yang terjadi disebabkan kredit macet nasabah. Dengan adanya jaminan kredit, nasabah diharapkan memiliki komitmen untuk berperilaku positif sehingga dikemudian hari bank tidak harus mengalami kerugian karena menanggung risiko yang timbul. Semakin besar nilai jaminan yang diberikan debitur pada saat penerimaan kredit maka keseriusan debitur dalam mengembalikan kredit akan semakin tinggi agar jaminannya dapat kembali. Hasil penelitian ini mendukung Azizah et al. (2020) yang menyatakan bahwa nilai jaminan tidak berpengaruh terhadap kelancaran pengembalian pembiayaan.

\section{SIMPULAN DAN SARAN}

\section{Simpulan}

Berdasarkan dari hasil penelitian ini, maka dapat disimpulkan sebagai berikut :

1. Berdasarkan hasil analisis menunjukkan bahwa tidak semua variabel berpengaruh terhadap kelancaran pengembalian kredit, dari semua variabel penelitian yang tidak berpengaruh diantaranya variabel karakter peminjam, besar pinjaman, sektor ekonomi dan jaminan kredit.

2 Faktor-faktor yang berpengaruh terhadap kelancaran pengembalian kredit di PT. Bank Perkreditan Rakyat Kawan adalah lama usaha dan cash flow. Lama usaha memiliki pengaruh dan keterkaitan positif dengan kelancaran pengembalian kredit. Artinya, semakin lama usaha maka peluang dan kecenderungannya untuk dapat mengembalikan kredit dengan lancar semakin tinggi. Begitu pula dengan cash flow memiliki pengaruh dan keterkaitan positif terhadap kelancaran pengembalian kredit. Artinya, semakin besar cash flow maka peluang dan kecenderungannya untuk dapat mengembalikan kredit dengan lancar semakin tinggi.

3. Dari hasil koefisien regresi determinasi terlihat bahwa R Square sebesar 0.619. Besarnya angka koefisien determinasi 0.287 atau sama dengan $61,9 \%$. Angka tersebut memiliki arti bahwa sebesar $61,9 \%$ kelancaran pengembalian kredit dapat dijelaskan dengan variabel karakter peminjam, besar pinjaman, sektor ekonomi, lama usaha, cash flow, dan jaminan kredit, sedangkan sisanya yaitu 38,1\% dapat dijelaskan oleh faktor-faktor penyebab lainnya.

\section{Saran}

PT. Bank Perkreditan Rakyat Kawan diharapkan untuk lebih selektif dan menerapkan prinsip kehati-hatian dalam memberikan pinjaman kredit dengan mempertimbangkan lama usaha dan cash flow dari calon debitur untuk mengantisipasi dalam penunggakan kredit. Namun berdasarkan metode pemilihan sampel yang digunakan, hasil penelitian memiliki kemungkinan tidak merepresentasikan seluruh debitur PT. Bank Perkreditan Rakyat Kawan, sehingga diperlukan penelitian lanjutan.

\section{DAFTAR PUSTAKA}

Abadi, Adit Fairuz. (2014). Analisis Pengaruh Karakteristik Peminjam, Besar Pinjaman, Jenis Usaha, dan Lama Usaha Terhadap Tingkat Kelancaran Pengembalian Kredit Usaha Rakyat (KUR) Mikro ( Studi Kasus pada Debitur KUR Mikro BRI Unit Kendal Kota). Skripsi FEB, Universitas Diponegoro.

Azizah, Nur, Reny Fitriana Kaban, Puji Hadiyat. 2020. Pengaruh Omzet Usaha dan Nilai Jaminan Terhadap Kelancaran Pengembalian Pembiayaan Murabahah Nasabah UMKM (The Effect of Turnover and Collateral Value on The Smooth Repayment of Murabahah Financing for MSME Customers). Perisai: Islamic Banking and Finance Journal. Vol. 4. Issue 2: 126-138.

Chandrarin, Grahita. 2017. Metode Riset Akuntansi Pendekatan Kuantitatif. Jakarta: Salemba Empat.

Kasmir. 2014. Bank dan Lembaga Keuangan Lainnya.Jakarta : Rajawali Pers.

Kuncoro, Mudrajad. 2001. Metode Kuantitatif Teori Dan Aplikasi Untuk Bisnis dan Ekonomi. AMP YKPN. Yogyakarta.

Kusumaningtyas, Ika. (2017). Pengaruh Karakteristik Personal, Karakteristik Usaha, Karakteristik Kredit, dan Jaminan terhadap Tingkat Pengembalian Kredit di BPR Nusamba Adiwerna Kabupaten Tegal Tahun 2016. Jurnal MULTIPLIER, I (2). 
Lestari, Julinda dan Media Rosha. 2020. Faktor Yang Mempengaruhi Tingkat Pengembalian Kredit Pada Program Simpan Pinjam Kelompok Perempuan (SPP) Menggunakan Analisis Regresi Logistik Biner. UNP Journal of Mathematics. Vol. 3 No 1:37-41.

Muhamammah, Eka Nur. 2008. Analisis Faktor-Faktor yang Mempengaruhi Tingkat Pengembalian Kredit Oleh UMKM (Studi Kasus Nasabah Kupedes PT. BRI, Tbk (Persero) Unit Cigudeg, Cabang Bogor). Skripsi : Institut Pertanian Bogor.

Nastiti, Anggri. (2012). Analisis Faktor-Faktor Yang Mempengaruhi Tingkat Pengembalian Kredit Pengusaha Kecil Pada Program Kemitraan (Studi Kasus: PT. PLN (Persero) Distribusi Jawa Timur Area Malang). Jurnal Akuntansi. Universitas Brawijaya Malang.

Undang-undang Indonesia.Undang-undang Perbankan Nomor 10 tahun 1998. 